\title{
The Marking System in the Dialect of Lamalera
}

\author{
Yosef Demon \\ Faculty of Teacher Training and Education, Flores University, Ende, Indonesia
}

\section{Email address:}

yosefdemon_bataona@yahoo.com,demomaung051065@gmail.com

\section{To cite this article:}

Yosef Demon. The Marking System in the Dialect of Lamalera. International Journal of Language and Linguistics. Vol. 5, No. 4, 2017, pp. 105-120. doi: 10.11648/j.ij11.20170504.14

Received: April 28, 2017; Accepted: May 20, 2017; Published: July 20, 2017

\begin{abstract}
Marking is a universal linguistic phenomenon. Marking is the giving of a marker either free or bound, either in front or back on a morphological form. The Dialect of Lamalera (DL) is one of 35 dialects in the Lamaholot Language family. The Lamalera dialect has apronominal marker attached either to the front in a number of certain categories of words or back in other categories. Interestingly, the DL is almost entirely in all categories of words. Provision of markers on anumber of categories triggers conformity to the word category often referred to as agreement verbs, personal clitics, subject markers, personal (prefixes, suffixes), agreement markers, or subject verb agreements. This paper will only examine the alignment in the DL with out comparing it with dialect or other languages cross language.
\end{abstract}

Keywords: Clitic, Proclitic, Enclitic, Verb Agreement

\section{Introduction}

Marking is actually a universal linguistic phenomenon. Marking is not artificial but natural [1,5]. Marking is the giving of a marker either free or bound, either in front or back on a lingual form. Marking is a morphological event in the syntactic process [25]. This means giving a mark up to a word that becomes the basic syntax constituent. The basic order constituents of a syntactic construct will gain markers as the distinguishing identity between none constituent and another constituent in a clause.

Marking in each language is very unique and diverse. Marking becomes a marker of basic inter connected relational relationships in a sentence series. Each language has a peculiarity to express the grammatical relationship between constituents and expresses the difference between one relation to another in a clause [19].

Marking in DL has a unique characteristics it is crosslanguage. Lamalera Dialect can mark all categories of words. However, to represent grammatical relations, not all syntactic categories get markers as core constituents.

\section{Discussion}

\subsection{Theoretical Review}

Syntactic theory states that grammatical relation, case marking, and agreement are always directly or indirectly related [29]. Grammatical relations describe the concepts of basic concepts such as subjects, objects, indirect objects [28, 19]. The case of marking is a reference to a number of referents in terms of macro rules closely related to the status of the core argument. Likewise, the conformity will refer to a reference by macro rule.

The concept of narrations for the linguist still disputes the argument. The substantive thing that underlies this concept of separation is the difference in the language system of every language. Whatever the concepts used still refer to the peculiarities of each language. Marking is referred to as the pronominal clause $[23,8]$, as the conformity of the pronouns [14], as the pronounced pronoun [21], as clitic [19, 15], as abound pronominal [20], and or as verbalized stem [6], assubject-verb agreement [3], and or as apronominal prefix and a pronominal suffix [13]. The existence of the linguist's concept of narration still refers to the peculiarities of the irrespective languages. Thus, the difference between concepts is a linguistic treasure that needs to be exploited.

The Lamalera Dialect is one of 35 dialects in Lamaholot 
[18]. The Lamalera dialect speakers are approximately 2500s who inhabit the area of Lamalera Village (A and B) and spread almost in all corners of the archipelago. The Lamalera Dialect has only one single dialect. The Dialect of Lamalera has no ergative language features such as languages in the Austronesian family, such as Tagalok, Filipino languages, and languages in North Sulawesi [11].

Based on the aspect of the relationship, the classification is grouped into formal formalization and functional delineation [10]. Marked marking generally uses particles attached to a morphological form either at the beginning or at the end, either tied or separated [16, 30]. Unmarked marking is phonological, meaning by using phonological features such as intonation patterns and pitch patterns to mark an $\mathrm{FN}$ or argument $[10,12]$.

On the basis of this theoretical exposition, the marking in the DL refers to the marking of a morphological form either at the beginning or at the end and is firmly attached to the morphological form both pre-empirical and free-base. Marking tends to be a system at the clause level and its use is very cautious. This caution is closely related to the distinction between clitic and affixes. Explicitly the two morphological forms are the same but if examined more thoroughly then these two morphological forms are very different [10]. The differences between these two forms of morphology refer to various linguistic opinions [24, 2, 27, 4, 19] as follows:

1) The affix added to as tem verb has one unified function as a word (one phonological entity). Clitic is a separate grammatical element, recognized as a separate unit of the word, can not stand al one, and is not a phonological entity.

2) Affix is a unity of the word that is attached, has meaning and pressure. Clitic are generally embedded in words and are not recognized as words.

3) Affixes are always restricted to use as formers of certain categories of words. Clitic can form sever al categories of words.

4) Derivational affixes and inflexion affixes always match according to the environment it enters. Clitic is not so.

5) The inflection process is always done after the derivational process. Clitic is added after the process of derivation and in flexion processes.

Referring to the parameter of affix and clitic differentiation as described and taking in to account the characteristic of DL, the researcher can say that the five parameters of affixes and clitic are met. This means that there is almost no difference between affix and clitic in DL. Thus, there should be another parameter that can be used as a determinant of the distinction between affix and clitic in DL.

As for other parameters which state that clitic is characterized as apronominal element which has no pressure and has a different syntactic distribution than powerful pronouns and full arguments [26]. In addition to these parameters, other parameters used are testing using a movement approach and a base-generation approach. The displacement approach states that the clitic initially occupies the position of the object and experiences displacement to the surface position joining the verb. The basic- derived approach states that the origin is a clause joining a verb [30, 26].

Referring to the parameters put forward by Scaeffer and Zagona, it can be said that the marking in DL has the characteristics:

1). Elements of pronominal attached to a morphological form either at the beginning or at the end;

2). Clitic occupies the starting position on the precategorical verb and end position on the pre-category and free basic verbs and other word categories.

Based on the cross-language theoretical analys is of the affirmation of affixes with the affixes in this paper is the pronominal clause.

\subsection{Marking in Lamalera Dialect}

Markings in DL are grouped according to positioning and by word category. Nevertheless, these two markers are described simultaneously. Principally, it is distinguished by the early or prolitlic marking and the final or enclitic marking [19].

\subsubsection{Proclitic Marking}

Proclitic alignment is the corresponding verb with the pronominal it follows. There is a correspondence between the verb and the subject [3], or there is a correspondence of the mark [25, 7] or there is acompliant pronoun [14]. This suitability or conformity at the beginning of this applies to pre-categorical categories such as verbs, modalities, conjunctions and demonstratives.

\section{(i). The Proclitic Marking of Intransitive Pre-categorical Verbs}

Based on the self-sufficiency aspect as a word, the categoryof verbs in DL is distinguished over pre-categorical verbs and free basic verbs. The pre-categorical verbs indicate that this category of verbs has not yet performed the syntactic function independently. Proclitic marking for pre-categorical intransitive verb can be observed in the following example.

1a) Goe $\mathrm{k}=$ ai vule $1 \mathrm{TG} 1 \mathrm{TG}=$ pergi pasar 'Saya pergi ke pasar' 'I go to the market'

1b) Moe $m=$ ai vule $2 \mathrm{TG} 2 \mathrm{TG}=$ pergi pasar 'Engkau pergi ke pasar' 'You go to the market'

1c) Nae $n=$ ai vule 3TG 3TG = pergi pasar

'Dia pergi ke pasar'

'He goes to the market'

1d) Tite $t=$ ai vule 1JINK1JINK = pergi pasar

'Kita pergi ke pasar'

'We go to the market'

1e) Kame $m=$ ai vule 
1JINK 1JEKS = pergi pasar

'Kami pergi ke pasar'

'We go to the market'

1f) Mio $m=$ ai vule

$2 \mathrm{~J} 2 \mathrm{~J}=$ pergi pasar

'Kamu pergi ke pasar'

'You go to the market'

1g) Rae $r=$ ai vule

3J $3 \mathrm{~J}=$ pergi pasar

'Kita pergi ke pasar'

'They go to the market'

The lingual form of 'departing' is stated pre-categorical by$a i$. This form will function syntactically full if added to the clause at the beginning of this category as shown in example (1a-1g). The clitic form added at the beginning of the precategorical verb under goes a phonological or systematic adjustment of the verb $[17,22]$ systematically and regularly. This means that the added conformity of the added proclitic sounds natural and in accordance with the environments entered. If examined, then it can be said that there is a strong phonological influence on any proclitic allomorphic form.

Pragmatically, the disappearance or deletion of the clause subject does not affect the acceptance and the clues of the meaning of the clause. The acceptance and clarity of the clause can be understood because the speaker and the speech partner are in the same speech situation in order to understand the content of the conversation. The trace ability of the clause subject can be observed in the proclitic form that is firmly attached to the pre-categorical verb. Facilitating this understanding of the following will be restated example (1a1-1c) as the reinforcement of this thesis.

$\left.1 a^{1}\right) \mathrm{K}=$ ai vule

$1 \mathrm{TG}=$ pergi pasar

'Saya pergi ke pasar'

'I go to the market'

$\left.1 b^{1}\right) \mathrm{M}=$ ai vule

$2 \mathrm{TG}=$ pergi pasar

'Engkau pergi ke pasar'

'You go to the market'

$\left.1 c^{1}\right) \mathrm{N}=$ ai vule

3TG $=$ pergi pasar

'Dia pergi ke pasar'

'He goes to the market'

Some pre-categorical verbs that experience the addition of the proliferative form as sample amplifier (1a-1g) can be observed in table 1 below.

Table 1. Forms of Proclitic Verbs Pre-categoricalin DL.

\begin{tabular}{|c|c|c|c|c|c|c|c|c|}
\hline \multirow{4}{*}{ Glos } & \multirow{4}{*}{ Prakategorial } & \multicolumn{7}{|l|}{ Persona } \\
\hline & & \multicolumn{3}{|l|}{ Singular } & \multicolumn{4}{|l|}{ Plural } \\
\hline & & 1 & 2 & 3 & 1Ink. & 1Eks. & 2 & 3 \\
\hline & & Goe & moe & nae & Tite & kame & mio & rae \\
\hline Ada (ber-) & $-a l a$ & $k=a l a$ & $m=a l a$ & $n=a l a$ & $t=a l a$ & $m=a l a$ & $m=a l a$ & $r=a l a$ \\
\hline bersama & $-a$ & $k=a$ & $m=a$ & $n=a$ & $t=a$ & $m=a$ & $m=a$ & $r=a$ \\
\hline bermalam & $-i e$ & $k=i e$ & $m=i e$ & $n=i e$ & $t=i e$ & $m=i e$ & $m=i e$ & $r=i e$ \\
\hline
\end{tabular}

\section{(ii). The Proclitic Marking of Transitive Pre-Categorical Verbs}

Proclitical alignment is not only in the intransitive pragmatic verb category but also occurs intransitive precategorical verbs. The following example shows what it means.

2a) Goe $\mathrm{k}=$ oi kbalake $\mathrm{n}=$ aw (p) e

$1 \mathrm{TG} 1 \mathrm{TG}=$ lihat laki. $3 \mathrm{TG}=\mathrm{itu} 1 \mathrm{TG}$

'Saya melihat laki-laki itu'

'I saw the man'

2b) Moe $\mathrm{m}=$ oi kbalake $\mathrm{n}=$ aw (p) e

2TG $2 \mathrm{TG}=$ lihat laki. $3 \mathrm{TG}=\mathrm{itu} 2 \mathrm{~J}$

'Engkau melihat laki-laki itu'

'You saw the man'

2c) Nae $n=$ o i kbalake $n=$ aw (p) e

3TG $3 \mathrm{TG}=$ lihat laki. 3TG $=$ itu3 J

'Dia melihat laki-laki itu'

'He saw the man'

2d) Tite $\mathrm{t}=$ oi kbalake $\mathrm{n}=$ aw (p) e

$1 \mathrm{JINK} 1 \mathrm{JINK}=$ lihat laki. $3 \mathrm{TG}=\mathrm{itu}$

'Kita melihat laki-laki itu'

'We saw the man'

2e) Kame $m=$ oi kbalake $n=a w(p)$ e
1JEKS 1JEKS = lihat laki. 3TG = itu

'Kami melihat laki-laki itu'

'We saw the man'

2f) Mio $m=$ oi kbalake $n=a w(p)$ e

2J 2J = lihat laki. 3TG = itu

'Kamu melihat laki-laki itu'

'You saw the man'

2g) Rae $\mathrm{r}=$ oi kbalake $\mathrm{n}=$ aw (p) e

3J 3J = lihat laki. 3TG $=$ itu

'Mereka melihat laki-laki itu'

'They saw the man'

The lingual form of 'seeing, knowing' is a transitive precategorical verb form. Semantically 'seeing, knowing' desires the presence of two arguments. A pre-verba argument is an agent and a post-verba argument is a direct object. The presence of pronominal agents will greatly influence the lingual shaping of the pre-categorical. The forms of conformity will change according to the preceding pronominal subject as seen in example (2a-2f).

Pragmatically the agent on each clause can be wiped out. This trace ability trace can be observed in the proclitic form attached to the pre-categorical verb. Such completeness or perception does not affect the clarification and acceptance of 
the meaning of the clauses. This is understandable because the speaker and the speech partner are in a similar speech situation so that both understand the content of the conversation as seen in the following sample (2a1-2c1):

$\left.2 \mathrm{a}^{1}\right) \mathrm{K}=$ oi kbalake $\mathrm{n}=\mathrm{aw}(\mathrm{p}) \mathrm{e}$
$1 \mathrm{TG}=$ lihat laki. 3TG = itu
'Saya melihat laki-laki itu'
'I saw the man'
$\left.2 \mathrm{~b}^{1}\right) \mathrm{M}=$ oi kbalake $\mathrm{n}=\mathrm{aw}(\mathrm{p}) \mathrm{e}$
$2 \mathrm{TG}=$ lihat laki. $3 \mathrm{TG}=\mathrm{itu}$

'Engkau melihat laki-laki itu'

'You saw the man'

$\left.2 c^{1}\right) \mathrm{N}=$ oi kbalake $\mathrm{n}=$ aw $(\mathrm{p}) \mathrm{e}$

$3 \mathrm{TG}=$ lihat laki. $3 \mathrm{TG}=\mathrm{itu}$

'Dia melihat laki-laki itu'

'He saw the man'

The following transitive preliminary verbs will be presented as reinforcement of this thesis.

Table 2. Consistency of Phonological Adjustment of Persona in DL Verbs.

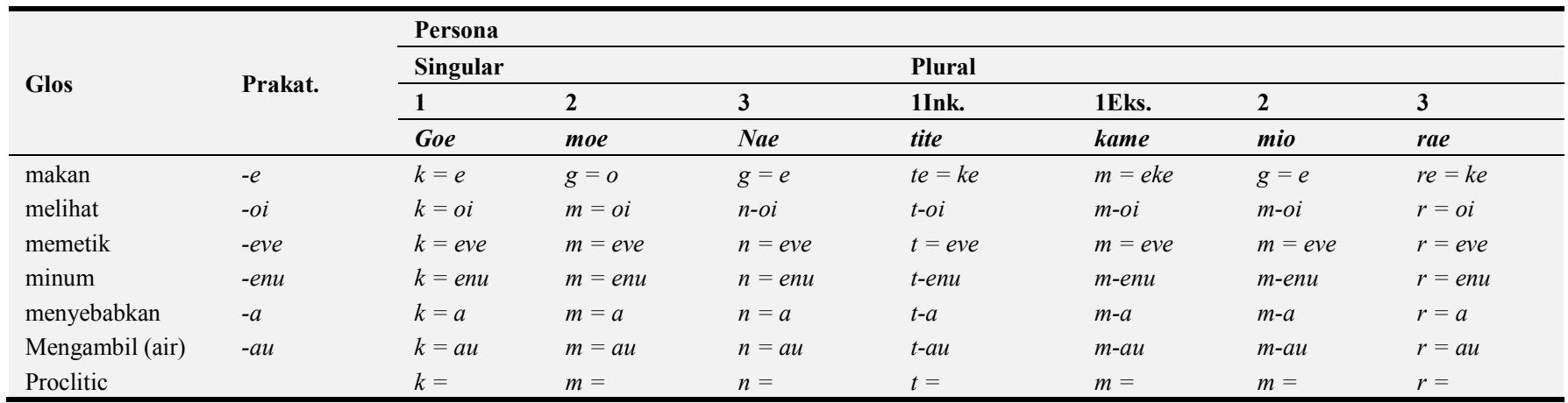

Table 2 states that there are phonological exceptions occurring in pre-categorical verbs 'eating' $-a$. The phonological exceptions only occur in the second and the third single pronominal forms. Nevertheless, the changes that occur in the 'eat' verb are phonological changes that can only be phonologically explained as well.

\section{(iii). The Proclitic Marking of Moods Category}

Other word pre-categorical lexical forms proclitic in addition to verbs are capital categories. Marking in the moods category can be observed in the following example.

3a) Goe $\mathrm{k}=$ ode mari ara antak $\mathrm{n}=$ aw (p) e na alep

$1 \mathrm{TG} 1 \mathrm{TG}=$ boleh omong tapi barang $3 \mathrm{TG}=\mathrm{itu}$ ada pemilik

'Kita boleh berbicara tapi barang itu milik orang (menyilahkan)' (invite)

'We may speak but something belongs to people

3b) Mio $\mathrm{m}=$ ode $\mathrm{g}=\mathrm{e} \mathrm{ki}$

$2 \mathrm{~J} 2 \mathrm{~J}=$ boleh $2 \mathrm{~J}=$ makan dulu

'Kamu boleh makan dulu (menyilahkan)'

'You can eat first (invite)'

3c) Rae $\mathrm{r}=$ ode tede nae ki

3J 3J = boleh tunggu 3TG dulu

'Mereka boleh menunggu dia dulu (menyilahkan)'
'They may wait for him first (invite)'

3d) Moe $m=$ ata mari nae

2TG $2 \mathrm{TG}=$ musti omong $3 \mathrm{TG}$

'Engkau harus berbicara dengan dia'

'You must speak with him'

3e) Goe $\mathrm{k}=$ ata mari nae $\mathrm{ki}$

$1 \mathrm{TG} 1 \mathrm{TG}=$ harus omong $3 \mathrm{TG}$ dulu

'Saya harus berbicara dengan dia terlebih dulu'

'I must talk to him first'

3f) Nae $n=$ abe $g=$ e ki

3TG $3 \mathrm{TG}=$ harus $3 \mathrm{TG}=$ makan dulu

'Dia harus makan dulu (meminta)'

'He must eat first (asking)'

$3 \mathrm{~g}$ ) Tite $\mathrm{t}=$ abe tede nae $\mathrm{ki}$

1JINK $1 \mathrm{JINK}=$ harus tunggu $3 \mathrm{TG}$ dulu

'Kita harus menunggu dia dulu (meminta)'

'We must wait for him first (ask/plead)'

The lingual form 'may, must, must be' declared precategorically. These lingual forms have not yet been able to carry out syntactic functions in the absence or exclusion of the pronominal proclitic of the subject (agent) in to these forms as seen in example $3 \mathrm{a}-3 \mathrm{~g}$. Formal changes are very systematic. The change of the three forms of capital categories can be observed in the following 3 thicknesses.

Table 3. Adjustment of Capital Pre-categorial Form.

\begin{tabular}{|c|c|c|c|c|c|c|c|c|}
\hline \multirow{3}{*}{ Glos } & \multirow{3}{*}{ Pre-categorical } & \multicolumn{3}{|l|}{ Singular } & \multicolumn{4}{|l|}{ Plural } \\
\hline & & 1 & 2 & 3 & 1 & 1 & 2 & 3 \\
\hline & & Goe & moe & Nae & tite & kame & io & rae \\
\hline harus & $-a b e$ & $k=a b e$ & $m=a b e$ & $n=a b e$ & $t=a b e$ & $m=a b e$ & $m=a b e$ & $r=a b e$ \\
\hline harus & $-a t a$ & $k=a t a$ & $m=a t a$ & $n=a t a$ & $t=a t a$ & $m=a t a$ & $m=a t a$ & $r=a t a$ \\
\hline boleh & -ode & $k=$ ode & $m=$ ode & $n=$ ode & $t=o d e$ & $m=$ ode & $m=$ ode & $r=$ ode \\
\hline Enclitic & & $k=$ & $m=$ & $n=$ & $t=$ & $m=$ & $m=$ & $r=$ \\
\hline
\end{tabular}




\section{(iv). The Proclitic Marking in The Conjunction Category}

Marking proclitic on other categories of words such as category conjunction (preposition). Behavior change or the suitability of this pre-categorical form can be observed in the following example.

4a) Rae $r=$ ai sajo $r=$ a sape

$3 \mathrm{~J} 3 \mathrm{~J}=$ pergi pancing $3 \mathrm{~J}=$ dengan sampan

'Mereka pergi memancing dengan sampan'

'They went fishing by boat'

4b) Nae $n=$ ai sajo $n=$ a sape

$3 \mathrm{TG} 3 \mathrm{TG}=$ pergi pancing $3 \mathrm{TG}=$ dengan sampan

'Dia pergi memancing dengan sampan'

'He went fishing by boat'

4c) Moe $\mathrm{m}=\mathrm{a}$ eme $=\mathrm{m} \mathrm{m}=$ ai vule pasar

$2 \mathrm{TG} 2 \mathrm{TG}=$ dengan $(\mathrm{dan}) \mathrm{ibu}=\operatorname{POSS} 2 \mathrm{TG} 2 \mathrm{~J}=$ pergi

Engkau dengan ibumu ke pasar

'Engkau bersama ibunya ke pasar'
'You and your mother to market'

4d) Nae $n=a$ eme $=\varnothing r=$ ai vule

$3 \mathrm{TG} 3 \mathrm{TG}=$ dengan $(\mathrm{dan}) \mathrm{ibu}=$ POSS $3 \mathrm{TG} 3 \mathrm{~J}=$ pergi pasar

Dia dengan (dan) ibunya ke pasar

'Dia bersama ibunya ke pasar'

'He and his mother to market'

The lingual forms' with, and, together' denote syntactic independence as any other pre-category category. These forms will perform syntactically function independently if added pronominal proclitic. The interesting thing that can be observed in the example (4a-4d) is the lingual form' with, and, together' seems to have the same pre-categorical form. As for difference is pre-categorical $-a$ will mean the preposition if followed FN which is the opposite tool if the FN that followed it is not instrumental then the precategorical form $-a$ meaning conjunction. The change of the two forms of practicity can be observed in table 4 below.

Table 4. Adjustment of Conjunctional Pronunciation Proclitic Form.

\begin{tabular}{|c|c|c|c|c|c|c|c|c|}
\hline \multirow{3}{*}{ Glos } & \multirow{3}{*}{ Prakategorial } & \multicolumn{3}{|c|}{ Singular } & \multicolumn{4}{|l|}{ Plural } \\
\hline & & 1 & 2 & 3 & 1 & 1 & 2 & 3 \\
\hline & & goe & moe & Nae & tite & kame & mio & rae \\
\hline dengan & -oro & $k=$ oro & $m=$ oro & $n=$ oro & $t=$ oro & $m=$ oro & $m=$ oro & $r=$ oro \\
\hline dengan & $-a$ & $k=a$ & $m=a$ & $n=a$ & $t=a$ & $m=a$ & $m=a$ & $r=a$ \\
\hline Proclitic & & $k=$ & $m=$ & $n=$ & $t=$ & $m=$ & $m=$ & $r=$ \\
\hline
\end{tabular}

\section{(v). The Proclitic Marking in The Demonstrative Category}

Other proclitic marking as in the category demonstrative. Proliferation changes in this category of words can be observed in the following example.

5a) Ana keni $n=a w(p)$ e plae $=v(a)$

Anak kecil $3 \mathrm{TG}=\mathrm{itu}$ lari $=3 \mathrm{TG}$

'Anak kecil itu lari'

'The little boy ran away'

5b) Ana keni n-aw (p) i plae $=v$ (a)

Anak kecil $3 \mathrm{TG}=$ ini lari $=3 \mathrm{TG}$

'Anak kecil itu lari'

'The little boy ran away'

5c) Ana kresi $r=a w(p)$ e pana $=$ vi

Anak kecil 3J $=$ itu jalan $=3 \mathrm{~J}$

'Anak-anak kecil itu jalan'

'The children walk'

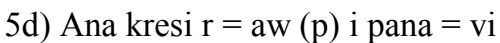

Anak kecil 3J $=$ ini jalan $=3 \mathrm{~J}$

'Anak-anak kecil itu berangkat'

'The children walk'

Changes that occur in this word category do not vary as in other word categories (verbs, modal, conjunction). Proliferation changes in demonstrative categories to express singularity and plurality. This means that the changed proclitic states that the nominal or pronominal it follows or explains is singular by using the proclitic $n$ - and plural form with the proclitic $r$-form as seen in example (5a-5d).

The example analysis (1-5) states that (a) the proclitic changes in the categories of verbs, modalities, conjunction sand demonstrative sare systematic, (b) the change in the proclitic form of the pre-categorical verbs- $a$ 'eat' is 'phonological' and not exceptions; or omission of the subject (agent) clause does not affect the meaning and meaning fullness of clauses, and (d) the proclitic form in the demonstrative category expresses the singular and plural noun or pronominal forms which it describes or explains. In general, changes in the form of proclitic verbs, modals, conjunction (preposition) and demonstrative can be observed in table 5 below.

Table 5. Consistency of Proclitic Verbal Changes to DL Previews.

\begin{tabular}{llllllll}
\hline & \multicolumn{1}{l}{ Persona } \\
\cline { 2 - 7 } & \multicolumn{1}{l}{ Tunggal } & \multicolumn{5}{l}{ Jamak } \\
\cline { 2 - 7 } & $\mathbf{1}$ & $\mathbf{2}$ & $\mathbf{3}$ & 1Ink. & 1Eks. & $\mathbf{2}$ & $\mathbf{3}$ \\
\hline & goe & moe & nae & tite & kame & mio & rae \\
\hline Proklitik & $k=$ & $m=$ & $n=$ & $t=$ & $k=$ & $m=$ & $r=$ \\
\hline
\end{tabular}

\subsubsection{Enclitic Marking}

The marking of the enclitic is the corresponding or corresponding verb with the pronominal it follows. If in the proclitic form, the pre-categorical lexical category is conformed at the beginning then the corresponding enclosure form will be performed at the end. Thus, once again phonological phenomena greatly affectt the change of the sounds.

The existence of sound variation is actually an allomorph representation of the forms because of the environment it enters. There is a suitability of verbs with the subject [3], or there is a correspondence of the mark [25] or there is a 
matching person pronoun [14]. This conformity or conformity only applies to phonologically, morphologically and syntactically independent lingual forms, such as free, possessive, reflexive, numerical and adjective verbs.

\section{(i). The Enclitic Marking in the Intransitive-Free Basic Verb Category}

The enclitic marking states the addition of a pronominal cluster that serves as the subject of the clause at the end of the free base verb. It says the basic verb is free because this lingual form is independent phonologically, morphologically and syntactically. The enclitic form in the basic free verbs can be observed in the following example.
6a) Go (e) plae $=$ ke
$1 \mathrm{TG}$ lari $=1 \mathrm{TG}$
'Saya lari'
'I run'away'
6b) $\mathrm{Mo}(\mathrm{e})$ pana = vo
$2 \mathrm{TG}$ jalan $=2 \mathrm{TG}$
'Engkau jalan'

\section{'You walk' \\ 6c) Nae tobo $=$ la \\ $3 \mathrm{TG}$ duduk $=3 \mathrm{TG}$ \\ 'Dia duduk' \\ 'He sat down'}

Unlike the case of pre-categorical verbs that will only be syntactically self-contained if added to the clause at the beginning of the verb. If in the proclitic form the sound changes are adjusted to the sound of the pronominal form followed then the free-form basis of sound change depends greatly on the final sound of the basic verb it self. This distinction is the basis for the distinction between proclitic and enclitic forms.

The changes in the form of the enclitic are very varied. The variability of the seen clitic forms is actually very dependent on the final sound of the basic form. Despite the soundness of sound but the sounds are allomorphic. Table 6 below will present a number of free basic verbs with these varied forms of enclosure.

Table 6. The Change of Free Basic Verb Enclitic Markingin DL.

\begin{tabular}{|c|c|c|c|c|c|c|c|c|}
\hline \multirow{3}{*}{ Gloss } & \multirow{3}{*}{ Verba } & \multicolumn{7}{|l|}{ Persona } \\
\hline & & \multicolumn{3}{|l|}{ Ingular } & \multicolumn{4}{|l|}{ Plural } \\
\hline & & 1 & 2 & 3 & 1Ink. & 1 Eks. & 2 & 3 \\
\hline lari & plae & $=k e$ & $=k o$ & $=v a$ & $=t e$ & $=k e m /=k m e$ & $=k r e$ & $=i r i$ \\
\hline naik & gere & $=k(e)$ & $=k o$ & $=v a$ & $=t e$ & $=k e m /=k m e$ & $=k r e$ & $=r i$ \\
\hline bangun & hogo & $=k(e)$ & $=k o$ & $=r a$ & $=t e$ & $=\mathrm{kem} /=\mathrm{kme}$ & $=k r e$ & $=r i$ \\
\hline karang & pnima & $=v k e$ & $=v o$ & $=v a$ & $=t e$ & $=k e m /=k m e$ & $=k r e$ & $=r i$ \\
\hline tidur & turu & $=v k e$ & $=k o$ & $=v a$ & $=t e$ & $=k e m /=k m e$ & $=k r e$ & $=r i$ \\
\hline suara (ber-) & ale & $=n g k e$ & $=n g o$ & $=n g a$ & $=$ ngte & $=n g k e m /=n g k m e$ & $=$ ngre & $=n g i$ \\
\hline berdiri & $d e i$ & $=n g k e$ & $=n g o$ & $=n g a$ & $=$ ngte & $=n g k e m /=n g k m e$ & $=$ ngre & $=n g i$ \\
\hline datang & beso & $=l k e$ & $=l o$ & $=l a$ & $=l t e$ & $=l \mathrm{kem} /=\mathrm{lkme}$ & $=$ lre & $=l i$ \\
\hline terjun & sole & $=n g k e$ & $=n g o$ & $=n g a$ & $=$ ngte & $=n g k e m /=n g k m e$ & $=$ ngre & $=n g i$ \\
\hline mandi & hebo & $=k(e)$ & $=k o$ & $-v a$ & $=t e$ & $=k e m /=k m e$ & $=k r e$ & $=r i$ \\
\hline$d u d u k$ & tobo & $=l k e$ & $=l o$ & $-l a$ & $=$ lte & $=l \mathrm{kem} /=l \mathrm{kme}$ & $=$ lre & $=l i$ \\
\hline Enclitic & & $=k e$ & $=o$ & $-a$ & $=t e$ & $=\mathrm{kem} /=\mathrm{kme}$ & $=r e$ & $=i$ \\
\hline
\end{tabular}

Table 6 illustrates that the addition of the enclosure form at the end of the free base verb is highly irregular. However, this does not mean that this phonological change can not be legislated. Any sound changes that occur are harmonic and natural so that can be explained and phonologically governed.

The proclitic forms firmly attached to the basic verbs indicate that if the clauses ubject is wiped out the clauses remain grateful and grammatical. This is understandable because pragmatically speaking, the speaker and the speech partner are in one line of speech and equally so as to understand the content of the conversation. The following example is a sample replication $(6 a-6 c)$ as a proof of this thesis.

$$
\begin{gathered}
\left.6 \mathrm{a}^{1}\right) \text { Plae }=\text { ke } 6 \\
\text { Lari }=1 \mathrm{TG} \\
\text { 'Saya lari' }
\end{gathered}
$$

$$
\text { 'I ran away' }
$$

$\left.6 b^{2}\right)$ Pana $=$ vo

Jalan $=2 \mathrm{TG}$

'Engkau jalan'

'You walk'

$\left.6 \mathrm{c}^{3}\right)$ Tobo $=$ la

Duduk $=3 \mathrm{TG}$

'Dia duduk'

'He sat down'

The trace ability of the subject can be observed through the tightly embedded form of attachment to the free base verb. The subjugation of the subject still gives information that the form is a declarative clause. If clauses subject to be lost then the enclitic form can be lost. The impregnation of the enclosure forms can be observed in the following sample $(6 a 2-6 c 2)$.

$\left.6 \mathrm{a}^{2}\right)$ Go (e) plae 
1 TG lari

'Saya lari'

'I ran away'

$\left.6 b^{2}\right)$ Mo (e) pana

2TG jalan

'Engkau jalan'

'You walk'

$\left.6 c^{2}\right)$ Nae tobo

3TG duduk

'Dia duduk'

'He sat down'

The impregnation of the enclosure form in the basic verb plae 'run', pana 'walk', tobo 'sit' syntactically is not problematic but semantically the enclosed form attached to the verb will give a different meaning to when the free base verb is not given the enclosure. Thus the attached form of the enclosure is not only useful in syntactic but also semantically.

\section{(ii). The Enclitic Marking in the Transitive-Free Basic Verb Category}

Destruction of other enclosed forms ontransitive-free basic verbs. The enclosure form in the transitive-free base verbs can be observed in the following examples.

7a) Goe glepa $=$ ro

$1 \mathrm{TG}$ pukul = 3TG

'Saya memukulnya'

'I hit him'

7b) Goe tbajak $=$ o ara nae taku $\mathrm{n}=$ ala mataj $=$ a hala

$1 \mathrm{TG}$ bunuh $=3 \mathrm{TG}$ tapi $3 \mathrm{TG}$ tidak $3 \mathrm{TG}=$ juga mati $=3 \mathrm{TG}$ tidak

'Saya membunuh-nya tetapi dia tidak mati'

'I killed him but he did not die'

7c) Agus tula $=$ ve lango

Agus buat $=3 \mathrm{~J}$ rumah

'Agus membuatkan mereka rumah'
'Agus make them home'

7d) Goe hoda $=$ ro

$1 \mathrm{TG}$ cium $=3 \mathrm{TG}$

'Saya mencium-nya'

'I kissed her/him'

The marker of the enclosure on the transitive-free basic verbs is very limited. This suggests that the basic transitivefree verb envelope marker is present only in the singular and plural third person pronominal. Other pronominal forms such as first and second singular and plural can not be encliticed but take the form intact. Thus, the free base verb envelope marker is only applicable to the singular and plural third pronominal functions as objects. The third, singular and plural pronominal enclitic marker changes are also not only varied by the $k=r(o)$ (3singular) and $=v e(3$ plural) markers. The enclitic $=k(r) o$ (3singular) and $=v e$ (3plural) forms may be removed and may be replaced by a single, triple intact singular pronominal form as shown in the following (7a1-7b1) example.

$\left.7 \mathrm{a}^{1}\right)$ Goe glepa nae

1TG pukul 3TG

'Saya memukulnya'

'I hit him'

$7 b^{1}$ ) Agus tula rae lango

Agus buat $3 \mathrm{~J}$ rumah

'Agus membuatkan mereka rumah'

'Agus make them home'

The impregnation of the enclosed- $k(r) o$ (3single) and -ve (3plural) forms will only result in an unacceptable or not grammatical form. This is due to the semantic valence of each verbal predator of each clause. A number of free basic verbs with third, singular and plural pronominal enclitic markers can be observed in table 7 below.

Table 7. The Third Pronominal Marking (Singular and Plural) in DL.

\begin{tabular}{|c|c|c|c|c|c|c|c|c|}
\hline \multirow{3}{*}{ Verbal } & \multirow{3}{*}{ Glos } & \multicolumn{7}{|c|}{ Persona } \\
\hline & & 1 & 2 & 3 & 1 Ink. & 1 Eks. & 2 & 3 \\
\hline & & Goe & moe & Nae & tite & kame & mio & rae \\
\hline baku & bangun & baku & baku & baku $=$ ro & baku & baku & baku & $b a k u=v$ \\
\hline dene & masak & dene & dene & dena $=r(o)$ & dene & dene & dene & dena $=v$ \\
\hline eka & turun & eka & $e k a$ & $e k a=r o$ & $e k a$ & $e k a$ & eka & $e k a=v$ \\
\hline veda & pancing & veda & veda & veda $=$ ro & veda & veda & veda & $v e d a=v$ \\
\hline hode & ambil & hode & hode & hodi $=$ ro & hode & hode & hode & hode $=v$ \\
\hline huak & urut & huak & huak & huak $=o$ & huak & huak & hua & $h u a=v$ \\
\hline enklitik & & - & - & $=o$ & - & - & - & $=v e$ \\
\hline
\end{tabular}

Clustering of enclitic in other pronominal forms (first/second singular and plural) as clause object arguments can not be quantized. As the argument or constituent occupying the function of the object the pronominal forms will take the form intact as seen in the following examples.

8a) Nae lulu goe oe

3TG gulung 1TG tikar

'Dia menggulung (-kan) saya tikar'

'He rolled me mat'

8b) Goe hopi moe labu
1TG beli 2 TG baju

'Saya membeli engkau baju'

'I bought you clothes'

8c) Nae tive kame hura

3TG buang 1 JEKS ubi

'Dia membuang (-kan) kami ubi'

'He threw us yam'

The popularization of this pronominal shape will result in an unacceptable and not grammatical form as seen in the following examples. 
9a) Nae glepa $=\mathrm{ke},=\mathrm{ko},=\mathrm{te},=\mathrm{kem} /=\mathrm{kme},=\mathrm{kre}$ $3 \mathrm{TG}$ pukul $=1 \mathrm{TG},=2 \mathrm{TG},=1 \mathrm{JINK},=1 \mathrm{IEKS},=2 \mathrm{~J}$, 'Dia memukul saya, engkau, kita, kami, kamu, mereka' 'He hit me, you, us, you they'

9b) Nae tbaja $=\mathrm{ke},=\mathrm{ko},=\mathrm{te},=\mathrm{kem} /=\mathrm{kme},=\mathrm{kre}$ $3 \mathrm{TG}$ bunuh $=1 \mathrm{TG},=2 \mathrm{TG},=1 \mathrm{JINK},=1 \mathrm{IEKS},=2 \mathrm{~J}$, 'Dia membunuh saya, engkau, kita, kami, kamu' 'He killed me, you, us, you'

\section{(iii). The Enclitic Marking in Numerical Category}

The marking of the enclitic in the numerical category states that the marking of a numerical category represents a collection. The enclitic barriers in the numerical categories can be observed in the following examples.

10a) Tite rua $=$ te $\mathrm{t}=$ ai vule $\mathrm{ki}$

$1 \mathrm{JINK}$ dua $=1 \mathrm{JINK} 1 \mathrm{JINK}=$ pergi pasar dulu

'Kita berdua pergi pasar dulu'

'We both go to the market first'

10b) Mio pat $=$ re tobo depe

$2 \mathrm{~J} 4=2 \mathrm{~J}$ duduk di. situ

'Kamu berempat duduk di situ'

'The four of you are sitting there'

10c) Rae lema $=$ ri taje ana $n$-awe

3J lima-3 J pukul anak 3TG = itu

'Mereka berlima memukul anak itu'

'The five of them hit the boy'

Example (10a-10c) states that the enclosed form attached to the numerical category of the 'three' races, the four" the 'fifth' means the' group, 'consisting of two or more entities. Some of the attractions of this envelope marker are (a) to express 'aggregates, groups', these markers can not be attached to a single pronominal form either first, second or third pronominal. This is understand able because to declare 'assemblies or groups' the membership of the entity consists of more than one or more, (b) the deletion of the subject of each clause permitted by the provisions of the enclitic marker will be a flake that refers to the subject (agent) in the following replication sample (10a1-10c1).

$\left.10 \mathrm{a}^{1}\right) \mathrm{Rua}=$ te $\mathrm{t}=$ ai vule $\mathrm{ki}$

Dua $=1 \mathrm{JINK} 1 \mathrm{JINK}=$ pergi pasar dulu

'Kita berdua pergi pasar dulu'

'We both go market first'

$\left.10 \mathrm{~b}^{1}\right)$ Pat $=$ re tobo depe

$4=2 \mathrm{~J}$ duduk di. situ

'Kamu berempat duduk di situ'

'The four of you are sitting there'

$\left.10 \mathrm{c}^{1}\right)$ Lema $=$ ri taje ana $\mathrm{n}=$ awe

Lima $=3 \mathrm{~J}$ pukul anak $3 \mathrm{TG}=\mathrm{itu}$

'Mereka berlima memukul anak itu'

'The five of them hit the boy'

Submission of the subject (agent) clause has no effect on the non-programmatic and unacceptable clauses. (c) the inclusion of the numerical category enclitic will make the clause unacceptable and not grammatical as seen in the following examples (10a2-10c2).

$\left.10 \mathrm{a}^{2 *}\right)$ Tite rua $=$ te $\mathrm{t}=$ ai vule $\mathrm{ki}$
$1 \mathrm{JINK}$ dua $=1 \mathrm{JINK} 1 \mathrm{JINK}=$ pergi pasar dulu

'Kita berdua pergi pasar dulu'

'We both go market first'

$\left.10 \mathrm{~b}^{2 *}\right)$ Mio pat $=$ re tobo depe

$2 \mathrm{~J} 4=2 \mathrm{~J}$ duduk di. situ

'Kamu berempat duduk di situ'

'The four of you are sitting there'

$10 \mathrm{c}^{2^{*}}$ ) Rae lema $=$ ri taje ana $\mathrm{n}=$ awe

3J $5=3 \mathrm{~J}$ pukul anak $3 \mathrm{TG}=\mathrm{itu}$

'Mereka berlima memukul anak itu'

'The five of them hit the boy'

The non-programmatic and ineffectual imprinting of the numerical category enclitic indicates that there is a close connection between the enclitic form and the numerals primarily to 'collection or group'. A number of basic numerals in DL with enclosure marking can be observed in table 8 below.

Table 8. Adjustment of the Enclitic Form in Numerical Category in DL.

\begin{tabular}{|c|c|c|c|c|c|c|c|}
\hline \multirow{3}{*}{ Numeralia } & \multicolumn{7}{|c|}{ Pronomina } \\
\hline & \multicolumn{3}{|c|}{ Tunggal } & \multicolumn{2}{|c|}{ Jamak } & \multirow[b]{2}{*}{2} & \multirow[b]{2}{*}{3} \\
\hline & 1 & 2 & 3 & 1 & 1 & & \\
\hline rua & - & - & - & $=t e$ & $=\mathrm{kem} / \mathrm{l}$ kme & $=k r e$ & $=r i$ \\
\hline telo & - & - & - & $=t e$ & $=\mathrm{kem} /=\mathrm{kme}$ & $=k r e$ & $=r i$ \\
\hline $\mathrm{Pa}$ & - & - & - & $=t e$ & $=\mathrm{kem} /=\mathrm{kme}$ & $=k r e$ & $=r i$ \\
\hline lema & - & - & - & $=t e$ & $=\mathrm{kem} / \mathrm{kme}$ & $=k r e$ & $=r i$ \\
\hline пети & - & - & - & $=t e$ & $=\mathrm{kem} /=\mathrm{kme}$ & $=k r e$ & $=r i$ \\
\hline
\end{tabular}

\section{(iv). Marking in the Noun (Possessive) Category}

Marking in the category of possessive nouns can also be expressed in the form of enclosures and also in the form of pronouns intact. These two possessive forms can substitute each other with the provision that there are bound or enclitic and there is a free form. Although the enclosure may be substituted with the free base form, the use of the possessive enclitic is very varied according to the end sound of a noun. If the final noun sound is a distinct vowel sound with the final sound of the consonant. The Enclitic form of the nouns ending the vowel sound can be observed in the following examples.

$\begin{array}{lll}\text { 11a) Alo langu }=\boldsymbol{\varnothing} & \text { lei }=\mathrm{t} & \text { kote }=\mathrm{r} \\ \text { Alo rumah }= & \text { kaki }= & \text { kepala }= \\ \text { POSS3TG } & \text { POSS1JINK } & \text { POSS3J } \\ \text { 'Rumahnya Alo' } & \text { 'kaki-kita' } & \text { 'kepala-mereka' } \\ \text { 'Alo's house' } & \text { 'Our leg' } & \text { 'Their head' }\end{array}$

11b) Nae tulis sura nei bape $=m$

3TG tulis surat untuk ayah $=$ POSS2TG

'Dia menulis surat untuk ayah-mu'

'He wrote a letter to your father'

11c) Go (e) dene bele = t vai

1TG masak/rebus nenek-POSS1JINK air

'Saya memasak (-kan) nenek air'

'I boil the water for our grand mother'

11d) Moe pu lama nei tata $=\mathrm{k}$ ki

2TG cuci piring untuk kakak-POSS1TG dulu

'Engkau mencuci piring untuk kakakmu dulu' 
'You wash dishes for your brother first'

11e) Mio ba alelolo nei ema $=$ kre ki

$2 \mathrm{~J}$ cuci pakaian untuk ibu-POSS2J dulu

'Kamu mencuci pakaian untuk ibumu dulu'
'You wash clothes for your mother first'

The distribution of the possessive enclitic in nouns ending with the vowels can be observed in table 9 below.

Table 9. The Possessive Enclitic Marker on The Noun Ends Vowel.

\begin{tabular}{|c|c|c|c|c|c|c|c|}
\hline Nomina & Singular & & & Plural & & & \\
\hline & 1 & 2 & 3 & 1INK & 1EKS & 2 & 3 \\
\hline & goe & moe & nae & Tite & kame & mio & rae \\
\hline lima & $\operatorname{lima}=k$ & $\lim a=m$ & $\lim a=\varnothing$ & $\operatorname{lima}=t$ & lima $=$ kem $/=k m e$ & lima $=$ kre & $\operatorname{lima}=r(i)$ \\
\hline lango & lang $u=k$ & lang $u=m$ & langu-ø & lang $u=t$ & lango $=$ kem $/=k m e$ & langu $=$ kre & langu $=r(i)$ \\
\hline$l e i$ & $l e i=k$ & $l e i=m$ & $l e i=\varnothing$ & $l e i=t$ & lei $=k e m /=k m e$ & lei $=k r e$ & $l e i=r(i)$ \\
\hline kote & kote $=k$ & kote $=m$ & kote $=\varnothing$ & kote $=t$ & kotekem / = kme & kote $=k r e$ & kote $=r(i)$ \\
\hline$l u v u$ & $l u v u=k$ & $l u v u=m$ & $l u v u=\varnothing$ & $l u v u=t$ & $l u v u=k e m /=k m e$ & $l u v u=k r e$ & $l u v u=r(i)$ \\
\hline
\end{tabular}

If the possessive enclitic in the noun-ending noun differs from the enclitic form of the nouns which ends in consonant then the following will be presented a possessive enclitic marker on the nouns ending in the consonant.

12a) Ktubeng $=\varnothing$ blara-blara

Punggung-POSS3TG sakit-RED

'Punggungnya sakit sekali'

'His back hurt so bad'

12b) Kbangor $=$ me blake

Dagu $=$ POSS2TG panjang

'Dagunya panjang'
'His long chin'

12c) Korok = re blara

Dada-POSS2J sakit

'Dada kamu sakit'

'Your chest hurts'

12d) Kluger $=$ ke blara vreke-ng

Mata kaki $=$ POSS1TG sakit sekali-SUF

'Mata kaki saya sakit sekali'

'My ankle hurts'

A number of nouns end with consonant sounds with the possessive enclitic marker observable in table 10 below.

Table 10. The Possessive Enclitic Marker on The Noun Ends Consonant.

\begin{tabular}{|c|c|c|c|c|c|c|c|c|}
\hline Glos & LDLL & Singular & & & Plural & & & \\
\hline & & 1goe & $2 m o e$ & 3nae & 1tite & 1 kame & $2 m i o$ & 3rae \\
\hline bahu & kvalek & $k$ valek $=k e$ & $k$ valek $=m e$ & kvalek $=\varnothing$ & kvalek $=$ te & kvalek $=$ kem $/=k m e$ & kvalek $=r e$ & kvalek $=i$ \\
\hline hidung & irung & irung $=k e$ & irung $=m e$ & irung $=\varnothing$ & irung $=$ te & irung $=\mathrm{kem} /=k m e$ & irung $=r e$ & irung $=i$ \\
\hline tulang & riuk & riuk $=k e$ & riuk $=m e$ & riuk $=\varnothing$ & $r i u k=t e$ & riuk-kem / = kme & riuk $=r e$ & riuk $=i$ \\
\hline ubun & klevuk & $k l e v u k=k e$ & $k l e v u k=m e$ & klevuk $=\varnothing$ & klevuk $=$ te & $k l e v u k=k e m /-k m e$ & $k l e v u k=r e$ & klevuk $=i$ \\
\hline lutut & volor & volor $=k e$ & volor $=m e$ & volor $=\varnothing$ & volor $=$ te & volor $=\mathrm{kem} /=\mathrm{kme}$ & volor $=r e$ & volor $=i$ \\
\hline
\end{tabular}

The change of the enclitic markers on the nouns ends in the vowels and the consonants show there is an absence and a difference. The similarities and differences between the two possessive enclitic forms can be observed in the following table11.

Table 11. Comparison of Possessive Enclitic Markers on Nomina of Vowels and Consonant Voice.

\begin{tabular}{|c|c|c|c|c|c|c|c|}
\hline \multirow{2}{*}{ Nomina } & \multicolumn{3}{|c|}{ Tunggal } & \multicolumn{4}{|c|}{ Jamak } \\
\hline & 1 goe & $2 m o e$ & 3nae & 1tite & 1 kame & $2 m i o$ & $3 r a e$ \\
\hline Enclitic/vowel & $=k$ & $=m$ & $=\varnothing$ & $=t e$ & $=\mathrm{kem} /=\mathrm{kme}$ & $=k r e$ & $=r i$ \\
\hline
\end{tabular}

The resemblance is the consistency of the third singular and first plural possessive enclitic. The enclitic possessive marker of the other pronoun form experiences the addition of sound as in the first and second pronominal forms while in the second and third the plural is experiencing sound eruption. The addition and expression of sound is actually a phonological phenomenon.

In addition to using the form of enclosure, the possessive form can also use the pronominal form intact. This means that for the sake of efficiency and effectiveness of speech tend to speakers use both forms in turn. The use of the whole possessive form can be observed in the following examples. 13a) Koteklema petu tena re? e $\mathrm{n}=$ oro bisa $=\mathrm{ka}$ Ikan paus pecah perahu POOS3 J $3 \mathrm{TG}=$ kasih pecah $=3 \mathrm{TG}$ 'Ikan paus memecahkan perahu mereka' 'Whale scrack their boat'

13b) Rae anak go? E

3J anak POSS1TG

'Mereka anak-anak saya'

'They are my children'

13c) Mio gnato (u) buku nei teme mo? E 2J kirim buku kasih teman POSS2TG 'Kamu mengirim buku untuk temanmu' 'You sent a book to your friends' 
13d)'Mria hupe guru ne?E, ee grengaj'

Mria jemput guru POSS3TG, muka senyum

'Maria menyambut gurunya, tersenyum'

'Mary welcomes her teacher, smiles'

The intact pronominal form as seen in these examples at a glance shows the same shape as the pronominal form.
However, if examined, it would appear that the whole possessive form undergoes changes such as (a) sound changes in the third pronominal singular and plural and (b) there is a vocal reverberation or the extension of the back vowel. The full possessive shape can be observed in the following table 12 .

Table 12. Wholeness of Possessive Pronouns.

\begin{tabular}{llllllll}
\hline & \multicolumn{7}{l}{ Pronomina } \\
\cline { 2 - 7 } & Tunggal & \multicolumn{7}{l}{ Jamak } \\
\cline { 2 - 7 } BentukUtuh & $\mathbf{1}$ & $\mathbf{2}$ & $\mathbf{3}$ & 1Ink. & 1Eks. & $\mathbf{2}$ & $\mathbf{3}$ \\
\cline { 2 - 7 } & go? $E$ & mo? $E$ & ne? $E$ & titt? $E$ & kam? $E$ & mi? o & re? E \\
\hline
\end{tabular}

\section{(v). Marking in the Reflexive Category}

Self-referenced appointments in DL can be expressed in an enclitic. This reflexive enclitic marker can be attached to two lexical forms which denote 'self' nimo and veki. The following will be presented an enclosure marker attached to the nimo lexical form in the following examples.

14a) Goe nimo = k (e) k= ai vate

$1 \mathrm{TG}$ sendiri $=$ Ref1TG $1 \mathrm{TG}=$ pergi pantai

'Saya sendiri ke pantai'

'I my self go to the beach'

14b) Kame nimo $=$ kem m-ai vate

1JINK sendiri-Ref1TG $1 \mathrm{JINK}=$ pergi pantai

'Kami sendiri ke pantai'

'We ourself go to the beach'

14c) Rae nimo $=$ ri $r=$ ai vate

$3 \mathrm{~J}$ sendiri-Ref1TG $3 \mathrm{~J}=$ pergi pantai

Mereka sendiri ke pantai'

'They them self go to the beach'

The position of the nimo reflexive enclosure form can also be floated to the end of the clause as seen in the following replication example (14a1-14c1).

$\left.14 \mathrm{a}^{1}\right)$ Goe $\mathrm{k}=$ ai vate nimo $=\mathrm{k}(\mathrm{e})$

$1 \mathrm{TG} 1 \mathrm{TG}=$ pergi pantai sendiri $=\operatorname{Ref} 1 \mathrm{TG}$

'Saya sendiri ke pantai'

'I my self go to the beach'

$\left.14 b^{1}\right)$ Kame $m=$ ai vate nimo $=$ kem

$1 \mathrm{JINK} 1 \mathrm{JINK}=$ pergi pantai sendiri-Ref1TG

'Kami sendiri ke pantai'

'We our self go to the beach'

$\left.14 \mathrm{c}^{1}\right)$ Rae $\mathrm{r}=$ ai vate nimo $=\mathrm{ri}$

3J $3 \mathrm{~J}=$ pergi pantai sendiri-Ref1 $\mathrm{TG}$

'Mereka sendiri ke pantai'

'They them self go to the beach'

Although it floats to the final position of the clause but ther eflexive enclitic form is still referring to the subject of the clause.

As already mentioned that to express 'self' DL uses two lexical forms nimo and veki. These two lexical forms can not be mutually substituted. Substituting the nimo form with veki will lead to the non-programmatic and unacceptability as seen in the following replication example (14a2-14c2).

$14 \mathrm{a}^{*}$ ) Goe veki $=\mathrm{ke} \mathrm{k}=$ ai vate

$1 \mathrm{TG}$ sendiri $=$ Ref $1 \mathrm{TG} 1 \mathrm{TG}=$ pergi pantai

'Saya sendiri ke pantai'

'I my self go to the beach'

$14 b^{*}$ ) Kame veki $=\mathrm{kem} m=$ ai vate

1 JINK sendiri-Ref1TG $1 \mathrm{JINK}=$ pergi pantai

'Kami sendiri ke pantai'

'We our self go to the beach'

$\left.14 \mathrm{c}^{*}\right)$ Rae veki $=$ ri $\mathrm{r}=$ ai vate

$3 \mathrm{~J}$ sendiri-Ref3 $\mathrm{J} 3 \mathrm{~J}=$ pergi pantai

'Mereka sendiri ke pantai'

'They them self go to the baceh'

Example 14 shows the use of lexical reflexive forms with reflexive markers. The use of reflexive enclical forms in lexical veki form can be observed in the following examples.

15a) Rae veki = ri blara

$3 \mathrm{~J}$ diri-Ref3J sakit

'Mereka (badan) sakit'

'They are sick (body)

15b) Nae veki $=\varnothing$ blara

3TG diri-Ref3TG sakit

'He is sick (body)'

'He is sick (body)'

15c) Moe veki $=\mathrm{m}$ blara

2TG diri-Ref2TG sakit

'Engkau (badan) sakit'

'You are sick (body)'

Example (15) indicates that (a) the veki form can not be floating like a nimo form. Floating positions will only lead to unacceptability and non-pragrammatics. (b) the veki form can not be substituted with nimo. Substitutional in equality is a distinction between these two lexical forms.

If these two forms are in one clause then, the nimo form must precede the veki form. There is a natural agreement that the speaker does not realize. The use of both forms simultaneously in a clause can be noted in the following examples.

16a)

Goe nimo $=k(e)$ tbajakv $\mathrm{eki}=(\mathrm{e})$

$1 \mathrm{TG}$ sendiri $=$ ReflTG

bunuh diri $=$ Ref1TG

'Saya bunuh diri sendiri'

'I my self killed my self'
Moe nimo $=$ ko tbajak veki $=$ $\mathrm{m}$

$2 \mathrm{TG}$ sendiri $=$ Ref2 $\mathrm{TG}$

bunuh diri $=$ Ref2TG

'Engkau bunuh diri sendiri'

'You your self killed your self' 
Tite nimo $=$ te tbajak veki $=\mathrm{t}$

(e)

Kita sendiri $=$ Ref1JINK

bunuh diri $=$ Ref1TG

'Kita bunuh diri sendiri'

'We our selves kill our selves'

The most basic thing that distinguishes these two lexical reflexive forms is the lexical reflexive form of nimo is aquasi-reflexive form. A pseudo-reflexive form means that this form can be transposed or put forward in to a topic position in topicalization construction. The lexical reflexive form of veki is the core form, meaning it is never transposed to occupy topical positions in topicalization construction. The difference between these two lexical reflexive forms can be observed in the following example (17a1-17b1).

17a) Arno tegel nimo $=$ va di blino
Arnol lihat diri $=3 \mathrm{TG}$ di cermin

'Arnol melihat dirinya di cermin'

'Arnol sees him self in the mirror'

$\left.17 \mathrm{a}^{1}\right)$ Nimo $=$ va tegel veki di blino

Diri $=3$ TG lihat diri di cermin

'Dirinya sendiri dilihat di cermin'

'Himself (Arnol) seen in the mirror'

17b) Nae pu lama nimo = va

3TG cuci piring sendiri-3TG

'Dia sendiri mencuci piring'

'He him self washed the dishes'

$17 \mathrm{~b}^{2)} \mathrm{Nimo}=$ va pu lama

Sendiri $=3$ TG cuci piring

'Dia sendiri mencuci piring'

'He him self washed the dishes'

The reflexive enclitic marker can be observed in the following table13.

Table 13. Adjustment of The Nimo and Veki Enclitic in The DL.

\begin{tabular}{|c|c|c|c|c|c|c|c|}
\hline \multirow{3}{*}{ BentukLeksikal } & \multicolumn{7}{|c|}{ Pronomina } \\
\hline & \multicolumn{3}{|l|}{ Singular } & \multicolumn{4}{|l|}{ Jamak } \\
\hline & 1 & 2 & 3 & 1 & 1 & 2 & 3 \\
\hline $\begin{array}{l}\text { Nimo } \\
\text { Enklitik } \\
\text { Veki } \\
\text { Enklitik }\end{array}$ & $\begin{array}{l}\text { nimo }=k e \\
=k e \\
\text { veki }=k e \\
=k e\end{array}$ & $\begin{array}{l}\text { nimo }=k o \\
=k o \\
\text { veki }=m \\
=m\end{array}$ & $\begin{array}{l}\text { nimo }=\varnothing \\
=\varnothing \\
\text { veki }=\varnothing \\
=\varnothing\end{array}$ & $\begin{array}{l}\text { nimo }=\text { te } \\
=t e \\
\text { veki }=t e \\
=t e\end{array}$ & $\begin{array}{l}\text { nimo }=k m e /-k m e \\
=k m e /=k m e \\
\text { veki }=k m e /=k m e \\
=k m e /=k m e\end{array}$ & $\begin{array}{l}\text { nimo }=\text { kre } \\
=\text { kre } \\
\text { veki }=\text { kre } \\
=\text { kre }\end{array}$ & $\begin{array}{l}\text { nimo }=r i \\
=r i \\
\text { veki }=r i \\
=r i\end{array}$ \\
\hline
\end{tabular}

\section{(vi). Marking in the Adjective Category}

Clarification of the enclitic may also occur in the adjective category as seen in the following examples.

18a) Ike vei $\mathrm{n}=$ awe hema-ng $=\mathrm{a}$ kae

Ikan air 3TG = itu basih-SUF = 3TG sudah

'Kuah ikan itu sudah basih'

'The fish sauce is already washed'

18b) Tite doa-ng = te kae we

$1 \mathrm{JINK}$ jauh-SUF $=1 \mathrm{JINK}$ sudah itu

'Kita sudah jauh'

'We are far away' 18c) Nae saje $=$ ve $n=$ ala kenilere va 3TG sayang $=3 \mathrm{TG} 3 \mathrm{TG}=$ sejak kecil. belum 'Dia menyayangi mereka sejak kecil'

'He loves him since childhood'

18d) One $=\mathrm{k}$ seneng $=\mathrm{ke}$ rae beso $=\mathrm{li}$

Dalam $=$ Poss1 TG senang $=1 \mathrm{TG} 3 \mathrm{~J}$ datang $=3 \mathrm{~J}$

'Hatiku senang mereka datang'

'My heart is glad they came'

A number of categories of adjectives with clitic markers can be observed in the following table 14 .

Table 14. The Enclitic Markers in The Adjective Category in DL.

\begin{tabular}{|c|c|c|c|c|c|c|c|}
\hline \multirow[t]{3}{*}{ Adjektive } & \multicolumn{7}{|c|}{ PronominaMarking } \\
\hline & \multicolumn{3}{|c|}{ Singular } & \multicolumn{4}{|l|}{ Plural } \\
\hline & 1goe & $2 m o e$ & 3nae & 1tite & 1 kame & $2 m i o$ & 3rae \\
\hline sanang & $=k e$ & $=o$ & $=a$ & $=t e$ & $=\mathrm{kem}$ & $=r e$ & $=i$ \\
\hline vauk & $=k e$ & $=o$ & $=a$ & $=t e$ & $=\mathrm{kem}$ & $=r e$ & $=i$ \\
\hline kteruk & $=k e$ & $=o$ & $=a$ & $=t e$ & $=\mathrm{kem}$ & $=r e$ & $=i$ \\
\hline klamur & $=k e$ & $=o$ & $=a$ & $=t e$ & $=\mathrm{kem}$ & $=r e$ & $=i$ \\
\hline lere & $=k e$ & $=k o$ & $=k a$ & $=k t e$ & $=\mathrm{kem}$ & $=k r e$ & $=k i$ \\
\hline blile & $=n g k e$ & $=n g o$ & $=n g a$ & $=$ ngte & $=$ ngkem & $=$ ngre & $=n g i$ \\
\hline blola & $=v k e$ & $=v o$ & $=v a$ & $=v t e$ & $=v k e m$ & $=$ vre & $=v i$ \\
\hline lela & $=j k e$ & $=j o$ & $=j a$ & $=j t e$ & $=j k e m$ & $=$ jre & $=r i$ \\
\hline & $=k e$ & $=(k),(n g),(v),(j) o$ & $=(k),(n g),(v),(j), a$ & $=(k),(n g),(v),(j)$ te & $=\mathrm{kem}$ & $=k r e$ & $=(k),(n g),(v),(r) i$ \\
\hline
\end{tabular}

Table 14 illustrates the change in the forms of the enclitic markers at the end of each highly variable adjective category tends to be unlawful. However, it does not mean that the form changes are unconstitutional. Changes in shape due to the environments entered are regular and natural so it can be phonologically governed. The shape complexity is an allomorph phenomenon.

\subsubsection{Combined Marking}

Composite alignment indicates that there is a proclitic addition of markers on a number of pre-categorical verbs then added with enclitic markers. The addition of the 
marking marker is done gradually. This means to a number of pre-categorical verbs will be given aproclitic then given the marker of the enclitic. So there is gradation or process in giving marking. The combined marker occurs only in the intransitive and transitive pre-categorical verb categories. Combined alignment in the intransitive and transitive precategorical verb categories will be presented below.

\section{(i). Combined Marking in the Intransitive Pre-categorical Verb Category}

Combined delineation in the category of pre-categorical verbs can be observed in the examples below.

19a) Moe $\mathrm{m}=\mathrm{ai}=\mathrm{ko} \mathrm{ki}$

$2 \mathrm{TG} 2 \mathrm{TG}=$ pergi $=2 \mathrm{TG}$ dulu

'Engkau pergi dulu'

'You go first'

19b) Nae $n=$ ai-ra nepen nule-ng

3TG 3 TG $=$ pergi-3TG tadi pagi-SUFJ

'Dia pergi tadi pagi'

'He left this morning'

19c) Kame $m=$ ia-ng = kem di me

$1 \mathrm{JEKS} 1 \mathrm{JEKS}=$ tunggu $=1 \mathrm{JEKS}$ di kebun

'Kami bermalam di kebun'

'We spent the night in the garden'

19d) Rae $\mathrm{r}=$ ia-ng = i di me

3J 3J = unggu-SUF $=3 \mathrm{~J}$ di kebun

'Mereka bermalam di kebun'

'They spend the night in the garden'

Composite alignment reflects the grading process done gradually. It means to obtain a phonological, morphological and syntactic form, a pre-categorical lingual form will be formed by proliferation. This is the basic ground because syntactically the pre-categorical form has not been able to carry out syntactic functions independently. By embedding the proclitic marker syntactically the pre-categorical form is meaningful, independent phonologically and morphologically. The proliferation of the proclict marks on this joint motion is something that absolutely needs to be done as a starting point for the combined declaration. The presence of enclitic markers is pragmatic and optional. The imprinting of the enclitic marker does not affect the acceptability and the clause of a clause as seen in the following replication example (19a1-19d1). 19a1) Moe $\mathrm{m}=$ ai ki

$2 \mathrm{TG} 2 \mathrm{TG}=$ pergi dulu

'Engkau pergi dulu'

'You go first'

19b1) Nae $\mathrm{n}=$ ai nepen nule-ng

3TG $3 \mathrm{TG}=$ pergi tadi pagi-SUF3 J

'Dia pergi tadi pagi'

'He left this morning'

19c1) Kame $m=$ ia di me

1JEKS $1 \mathrm{JEKS}=$ tunggu di kebun

'Kami bermalam di kebun'

'We spent the night in the garden'

19d1) Rae $r=$ ia di me

3J $3 \mathrm{~J}=$ tunggu di kebun

'Mereka bermalam di kebun'

'They spend the night in the garden'

The explosion of the proclitic marker on the predicate of the pre-categorical verb does not affect the acceptance and the clause of the clause. Nevertheless, it remains acceptable and remains grammatically pragmatic but semantically there is a difference of meaning. The deletion can also be done on the subject of the clause. The deletion of the clause subject also has no effect on the acceptability and the clauses as shown in the following replication example (19a2-19d2).

$\left.19 \mathrm{a}^{2}\right) \mathrm{M}=\mathrm{ai}=\mathrm{ko} \mathrm{ki}$

$2 \mathrm{TG}=$ pergi $=2 \mathrm{TG}$ dulu

'Engkau pergi dulu'

'You go first'

$\left.19 b^{2}\right) \mathrm{N}=\mathrm{ai}=$ ra nepen nule-ng

$3 \mathrm{TG}=$ pergi-3TG tadi pagi-SUF

'Dia pergi tadi pagi'

'He left this morning'

$\left.19 \mathrm{c}^{2}\right) \mathrm{M}=$ ia-ng = kem di me

$1 \mathrm{JEKS}=$ tunggu $=1 \mathrm{JEKS}$ di kebun

'Kami bermalam di kebun'

'We spent the night in the garden'

$\left.19 d^{2}\right) R=i a-n g=i$ di me

$3 \mathrm{~J}=$ tunggu $=3 \mathrm{~J}$ di kebun

'Mereka bermalam di kebun'

'They spend the night in the garden'

Some pre-categorical verbs with combined markers can be observed in the following table 15 .

Table 15. The Change of Enclitic Intransitive Pre-categorical Verbs in DL.

\begin{tabular}{|c|c|c|c|c|c|c|c|c|}
\hline \multirow{3}{*}{ Glos } & \multirow{3}{*}{ Verba } & \multicolumn{7}{|l|}{ Persona } \\
\hline & & \multicolumn{3}{|l|}{ Tunggal } & \multicolumn{4}{|l|}{ Jamak } \\
\hline & & 1 & 2 & 3 & 1Inklusif & 1Eksklusif & 2 & 3 \\
\hline pergi & $-a i$ & $k=a i-k e$ & $m=a i=k o$ & $n=a i=r a$ & $t=a i=t e$ & $m=a i=k e m /=k m e$ & $m=a i=k r e$ & $r=a i=r i$ \\
\hline $\begin{array}{l}\text { inap } \\
\text { Enklitik }\end{array}$ & $-i e$ & $\begin{array}{l}k=i a=n g k e \\
k-k e\end{array}$ & $\begin{array}{l}m=i a-n g=o \\
m=(=k) o\end{array}$ & $\begin{array}{l}n=i a-n g=a \\
n=a\end{array}$ & $\begin{array}{l}t=i a-n g=t e \\
t=t e\end{array}$ & $\begin{array}{l}m=i a-n g k \partial m /=k m e \\
m=k e m /=k m e\end{array}$ & $\begin{array}{l}m=i a-n g=r e \\
m=r e\end{array}$ & $\begin{array}{l}r=i a-n g=i \\
r=r i\end{array}$ \\
\hline
\end{tabular}

\section{(ii). Combined Marking of Transitive Categories Verbs}

The combined merging process of intransitive prerecord verbs also applies to transitive prelaboratory verbs. The provision of proclitic marking in the pre-categorical verb categories will first be given an enclitic marker. This process emphasizes that the provision of pro-local markers to pre- categorical verbs is absolute while the enclitic marker presentation in an autonomously independent form is pragmatic and optional. The following is acomposite exemplary example of a transitive preliminary verb.

20a) Kame $m=$ oi $=$ ve kae $1 \mathrm{JEKS} 1 \mathrm{JEKS}=$ lihat $=3 \mathrm{~J}$ sudah 
'Dia sudah melihat mereka'

'He has seen them'

20b) Rae $\mathrm{r}=\mathrm{oi}=$ ro kae

$3 \mathrm{~J} 3 \mathrm{~J}=$ lihat $=3 \mathrm{TG}$ sudah

'Mereka sudah melihat-nya'

'They've seen it'

20c) Moe $\mathrm{m}=$ eti $=$ ve ike rua

$2 \mathrm{TG} 2 \mathrm{TG}=$ bawa $=3 \mathrm{~J}$ ikan dua

'Engkau membawa mereka ikan dua ekor'

'You bring them two fish'

20d) Tite $\mathrm{t}=\mathrm{eti}=$ ro ike rua

1JINK1JINK = bawa $=3 \mathrm{TG}$ ikan dua

'Kita membawa-nya ikan dua ekor'

'We brought her a two-tailed fish'

20e) Goe $\mathrm{k}=$ oli = ro gouk kae

$1 \mathrm{TG} 1 \mathrm{TG}=$ bersih $=3 \mathrm{TG}$ habis sudah

'Saya sudah membersihkan-nya'

'I've cleaned it up'

20f) $\mathrm{Nae} \mathrm{n}=$ oli $=$ ve gouk kae

$3 \mathrm{TG} 3 \mathrm{TG}=$ bersih $=3 \mathrm{~J}$ habis sudah

'Dia sudah membersihkan semuanya (banyak)'

'He's cleaned up everything (alot)'

The attractiveness of the prerecorded preliminary verb juxt apposition is to allow only the three singular and pluralized encrypted pronoun markers to be embodied and embedded. Other forms of pronouns (first and second singular and plural) are permitted to take the form intact. The introduction of the enrich marker on this transitive preliminary verb is also actually a pragmatic phenomenon. This means that speakers often switch to using a more effective and efficient form by using a single and multiple plural pronominal enclitic. Thus a single pronominal encodulation and pluralism expresses the popularization of a single and a plural pronominal object. Forcing encryption on other pronominal forms (first/second singular and plural) will result in unacceptable and not grammatical clauses as seen in example 21a-21e.

21a) Mio $\mathrm{m}=\mathrm{oi}=\mathrm{k}$ kae

$2 \mathrm{~J} 2 \mathrm{~J}=$ lihat $=2 \mathrm{TG}$ sudah

'Kamu sudah melihat saya'

'You have seen me'

21b) Kame $m=o i=$ ro kae

2JEKS $2 \mathrm{JEKS}=$ lihat $=3 \mathrm{TG}$ sudah

'Mereka sudah melihatnya'

'They have seen him/her'

21c) Moe $\mathrm{m}=\mathrm{eti}=\mathrm{kem} /=\mathrm{kme}$ ike rua

$2 \mathrm{TG} 2 \mathrm{TG}=$ bawa $=1 \mathrm{JEKS}$ ikan dua

'Engkau membawa kami ikan dua ekor'

'You brought us two fishes'

21d) Rae $r=$ ete $=r$ ike rua

3J 3J = bawa- $=3 \mathrm{TG}$ ikan dua

'Mereka membawa dia ikan dua ekor'

'They brought him/her two fishes'

21e) Nae $\mathrm{n}=$ eti $=$ v vulu paja

$3 \mathrm{TG} 3 \mathrm{TG}=$ bawa $=3 \mathrm{~J}$ sayur pepaya

'Dia membawakan mereka sayur daun pepaya'

'He brought them papaya leaf' 21f) Nae $\mathrm{n}=$ eve $=\mathrm{kem} /=$ kme vulu paja

$3 \mathrm{TG} 3 \mathrm{TG}=$ petik $=1 \mathrm{JEKS}$ sayur pepaya

'Dia memetik kami sayur daun papaya'

'He plucks us leaf papaya'

If a single / plural first / second pronominal enclitic is allowed in DL, then DL can only allow the clause and cluster entries to be deleted. The clipping of the clause agent can be observed in the following replication example (20a1-20f1).

$\left.20 \mathrm{a}^{1}\right) \mathrm{M}=\mathrm{oi}=$ ve kae

$1 \mathrm{JEKS}=$ lihat $=3 \mathrm{~J}$ sudah

'Dia sudah melihat mereka'

'He has seen them'

$\left.20 b^{1}\right) \mathrm{R}=\mathrm{oi}=$ ro kae

$3 \mathrm{~J}=$ lihat $=3 \mathrm{TG}$ sudah

'Mereka sudah melihat-nya'

'They've seen it'

$\left.20 \mathrm{c}^{1}\right) \mathrm{M}=\mathrm{eti}=$ ve ike rua

$2 \mathrm{TG}=$ bawa $=3 \mathrm{~J}$ ikan dua

'Engkau membawa mereka ikan dua ekor'

'You bring them two fishes'

$\left.20 \mathrm{~d}^{1}\right) \mathrm{T}=$ eti $=$ ro ike rua

$1 \mathrm{JINK}=$ bawa $=3 \mathrm{TG}$ ikan dua

'Kita membawa-nya ikan dua ekor'

'We brought her a two-tailed fish'

$\left.20 \mathrm{e}^{1}\right) \mathrm{K}=$ oli = ro gouk kae

$1 \mathrm{TG}=$ bersih $=3 \mathrm{TG}$ habis sudah

'Saya sudah membersihkan-nya'

'I've cleaned it up'

$\left.20 \mathrm{f}^{\mathrm{l}}\right) \mathrm{N}=$ oli = ve gouk kae

$3 \mathrm{TG}=$ bersih $=3 \mathrm{~J}$ habis sudah

'Dia sudah membersihkan semuanya (banyak)'

'He's cleaned up everything (a lot)'

If in the example (20a1-20f1) the DL permits the deletion of the agent of each clause then the following replication example (20a2-20f2) DL also permits the deletion of the enclitic marker on each clause.

$20 a^{2}$ ) Kame $m=$ oi kae

1JEKS 1 JEKS = lihat sudah

'Dia sudah melihat'

'He's seen'

$20 b^{2}$ ) Rae $r=$ oi kae

3J 3 $=$ lihat sudah

'Mereka sudah melihat'

'They've seen'

$20 \mathrm{c}^{2}$ ) Moe $\mathrm{m}=$ eti ike rua

2TG $2 \mathrm{TG}=$ bawa ikan dua

'Engkau membawa ikan dua ekor'

'You brought two fish'

$\left.20 \mathrm{~d}^{2}\right)$ Tite $\mathrm{t}=$ eti ike rua

1JINK 1 JINK = bawa ikan dua

'Kita membawa ikan dua ekor'

'We bring two fishes'

$20 \mathrm{e}^{2}$ ) Goe $\mathrm{k}=$ oli gouk kae

1TG $1 \mathrm{TG}=$ bersih habis sudah

'Saya sudah membersihkan'

'I've cleaned up'

$20 f^{2}$ ) Nae $n=$ oli gouk kae 
3TG $3 \mathrm{TG}=$ bersih habis sudah

'Dia sudah membersihkan semuanya (banyak)'

'He's cleaned up everything (alot)'

The imprinting of the encllocation marker is an object 'sclogging'. Semantically the verb predator each clause requires two arguments. Apre-verba argument is an agent and apost-verba argument is an object. The disappearance or occurrence of a clitic object indicates that the transitive pretegorical verb predicate has allow transitivity. It is this condition that causes the imposition of the clitic object is permitted or permitted in the structure of the DL clause.

\subsection{The Meaning of the Marking}

An example study (1-21) states that DL enlarges all categories of words. It can be done primarily on precategorical and enclitic forms of free basic forms. Although it can be marked all categories but semantically the meaning of the differentiation between one category with an other category or between markers (proclitic/enclitic) which one type marking (proclitic/enclitic) the other. The following table 16 is a meaningful presentation of the markers contained in each word category.

Table 16. The Semantics Differences between Proclitic and Enclitic Verb in DL.

\begin{tabular}{|c|c|c|c|c|}
\hline \multirow{2}{*}{$\begin{array}{l}\text { Verbs Word } \\
\text { Category }\end{array}$} & \multicolumn{4}{|l|}{ Marking } \\
\hline & Proclitic & Meaning & Enclitic & Meaning \\
\hline Intransitive & $\mathrm{V}$ & $\begin{array}{l}\text { Referring to cross } \mathrm{S} \text {, denotes pronoun type, } \\
\text { pronoun form, and pronominal amount }\end{array}$ & $\mathrm{V}$ & $\begin{array}{l}\text { Referring to cross } \mathrm{S} \text {, denoting pronoun type, pronoun form, } \\
\text { pronoun number, express spontaneity aspect, and intesitas }\end{array}$ \\
\hline \multicolumn{5}{|l|}{ Pre-categorical } \\
\hline Transitive & $\mathrm{V}$ & $\begin{array}{l}\text { Referring to cross A, denotes the type of } \\
\text { pronoun, the pronoun form, and the pronominal } \\
\text { amount }\end{array}$ & $\mathrm{V}$ & $\begin{array}{l}\text { Object Clitization }(3 \mathrm{~S} / \mathrm{P}) \text {, states the pronoun type, pronoun } \\
\text { form, and the amount of pronouns }\end{array}$ \\
\hline \multicolumn{5}{|l|}{ Freeform } \\
\hline Transitive & - & - & $\mathrm{V}$ & $\begin{array}{l}\text { Object Clitization }(3 \mathrm{~S} / \mathrm{P}) \text {, states the pronoun type, pronoun } \\
\text { form, and the amount of pronouns }\end{array}$ \\
\hline Modals & $\mathrm{V}$ & $\begin{array}{l}\text { Referring to cross } \mathrm{S} / \mathrm{A} \text {, declaring the type of } \\
\text { pronoun, pronoun form, and pronominal amount }\end{array}$ & - & 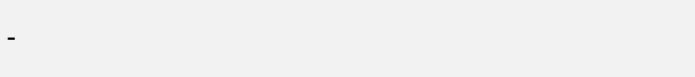 \\
\hline Demonstrative & & $\begin{array}{l}\text { Referring to the singularity or prestige of the } \\
\text { noun or pronominal it follows }\end{array}$ & - & - \\
\hline Possessive & - & - & $\mathrm{V}$ & Declare ownership or possession (possessiveness) \\
\hline Reflexive & - & - & $\mathrm{v}$ & Refers to 'self' and object \\
\hline Numerals & - & - & $\mathrm{v}$ & Declare the 'group or collection' of nouns it follows. \\
\hline Adjectives & - & - & $\mathrm{v}$ & $\begin{array}{l}\text { Refers to the subject of the clause and expresses the aspect of } \\
\text { the intensity or emphasis of the pronominal or nouns it } \\
\text { follows. }\end{array}$ \\
\hline
\end{tabular}

\section{Conclusion}

Marking is a universal linguistic phenomenon. Of course, as auniversal phenomenon of the interpretation of one language with another language is different. Often the parameters and explanations of a language marker are not necessarily the same as other languages. Nevertheless, there are similarities and differentiation that are knickknacks that color the universal perspective panorama.

There are similarities across languages if done comparative study. These similarities can occur because many factors such as language contact, derived from a single proto, clump, orsub-clumpare identical and may occur by chance. Of course, in addition there are also differences that can be examined from the aspects of language systems, phonological aspects, morphological, syntactic, semantic and pragmatic. This scientific truth can still be proved in more detail in further discussion if researchers have acuriosity about the universality of language.

Data analysis states that the marking in the DL is distinguished by (i) shifting based on the clitic position of proclitic and enclitic, and (ii) marking based on the category of words in DL such as sharpening of the pre-categorical (intransitive/transitive) verb categories, free (intransitive/transitive) verbs, possessive, reflexive, demonstrative and numeral), conjunctions and adjectives. Ingeneral, the markings in each category refer to the nouns or pronouns they follow. So there is a correspondence between the category of words explaining with nouns or pronouns.

Although referring to the noun or pronoun it follows, every marker (proclitic/enclitic) in each word category has a different meaning. Of course, the meaning is very dependent on the characteristics of the word category. The meaning of the marker in the category of the word is: (a) the meaning of the proclitic marker in the intransitive pre-categorical verb category is to cross $\mathrm{S}$, while the proclitic meaning of the transitive pre-categorical verbs refers to A. Besides referring to $\mathrm{S}$ and $\mathrm{A}$ the proclitic meaning in both these pre-categorical verbs is to declare the types of pronouns, pronouns, and pronominal numbers. As well as the meaning of proclitic on verbs, (b) the meaning of proclitic on the category of capital 
and the category of conjunction is to cross reference S/A clauses and declare the type pronominal, pronoun form, and pronominal amount, where as the meaning of proclitic in the category demonstrative is referring to singularity and plurality, (c) the meaning of the enclitic marker in the intransitive pre-categorical verb category is to cross $\mathrm{S}$ while the enclosure's meaning on the transitive pre-categorical verbs refers to $\mathrm{O}(3 \mathrm{~S} / \mathrm{P})$. In addition the second meaning of proclitic on both types of verbs is to declare the type of pronominal, pronoun form, the number of pronouns, express the aspect of spontaneity, and emphasizes, and (d) the meaning of the enclitic marker in the numeral category is to express the singularity or pronouns of the noun or pronominal it follows. The enclitic marker in the possessive category is to claim ownership or possessiveness, the meaning of the enclitic marker in the reflexive category to say 'self', and the meaning of enclosure in the adjective category is to refer to the subject clause and express the pronominal intensity or emphasize the noun that it followed.

\section{References}

[1] Anderson, John M. 1997. ANotional Theory of Syntactic Categories. Cambridge: Cambridge University Press.

[2] Arnol, B. T. and Choi, J. H. 2004. A Guide to Biblical Hebrew Syntax. Cambridge: Cambridge University Press.

[3] Arteaga and Herschenson in Auger, Julie., J. Clancy Cements, Barbara Vance (Ed.). 2003. Contemporary Approaches to Roman Lingistics. Amsterdam/Philadelphia: John Benjamins Publishing Company.

[4] Auger, Julie. Ed. 2003. Contemporary Approaches to Roman Lingistics. Amsterdam/Philadelphia: John Benjamins Publishing Company.

[5] Bauer, Laurie. 2003. Morphological Productivity. Cambridge: Cambridge University Press.

[6] Bromley, H. Myron. 1981. A Grammar of the Lower Grand Valley Dani. Australia, Canbera: Pacific Linguistics RSPAS, Australian National Universtiy.

[7] Carstairs, Andrew-McCharty in Bendjaballah, S. Ed. 2000. Morphology. Selected Papers From The $9^{\text {th }}$ Morphology Meeting, Vienna, 24-28February2000.

[8] Clackson, James. 2007. Indo-European Linguistics. An Introduction. Cambridge: Cambridge University Press.

[9] Demon, Yosef. Tipological Syntax Lamaholot Language Dialect Lamalera. Thesis. 2006. Postgraduate Program: Udayana University.

[10] Dixon, R. M. W. 2010. Basic Linguistic Theory. Volume 2. Grammatical Topics. Published in the United States of America: by Oxford University Press.

[11] Dixon, R. M. W. 2004. Ergativity. Cambridge: Cambridge University Press.
[12] Dixon, R. M. W. 2012. Basic Linguistic Theory. Volume 3. Further Grammatical Topics. Published in the United States of America: by Oxford University Press.

[13] Haan, Johnson Welem. 2001. The Grammar of Adang: A Papuan Language Spoken on the Island of Alor East Nusa Tenggara-Indonesia. Dissertation: Department of Linguistics, University of Sydney.

[14] Harris, Alice C. I981. Georgian Syntax. A Study in Relational Grammar. Cambridge: University Press.

[15] Hill, Jane, H. 2005. A Grammar of Cupeceno. Barkley, LosAngeles: Universityof California Press.

[16] Hinrichs, E., Kathol, A., Nakazawa, T. 1998. Syntax and Semantics Complex Predicates in Nonderivational Syntax. Vol. 30. CaliforniaAcademicPress.

[17] Hovav, M. R., Edit Doron, IvySichel. 2010. Lexical Semantics, Syntax and Event Structure. NewYork: Oxford Univeristy Press.

[18] Keraf, G. 1978. Morphology of the Lamalera Dialect. Ende/Flores: Arnoldus Offset Printing.

[19] Kroeger, PaulR. 2005. Analyzing Grammar. An Introduction. Cambridge: Cambridge University Press.

[20] Lehman, Winfred. P. and Helen Jo Jakusz Hewit. 1988. Language Typology. Typological Modelsin Reconstruction. Amsterdam/Philadelphia: Benjamins Publishing Company.

[21] Luis, Ana R. in Patience Epps, Alexandre Arkhipov. (Ed). 2009. New Challenges in Typology.

[22] Nishida, C. danJean-PierreY. Montreuil. 2006. New Perspectives on Romance Linguistics. Volume 1: Morphology, Syntax, Semantics, and Pragmatics. Philadelphia: John Benjamins Publishing Company Amsterdam.

[23] Núñez, Rafael-Cedeño, Luis Lópezin Auger (Ed.). 2003. A Romance Perspective on Language. John Amsterdam / Philadelphia: Benjamins Publishing Company.

[24] Quiles, C. 2007. A Grammar of Modern Indo-European. Fisrt Edition. Dnghu Adsoquiation: TheIndo-European Languages Associtaion.

[25] Quesada, J. Diego in Elisabeth Verhoeven, et al. 2008. Studies on Grammaticalization. New York: Mouton de Gruyter Berlin.

[26] Schaeffer, J. C. 2000. The Acquisition of Direct Object Scrambilng and Clitic. Placement syntax and Pragmatics. Amsterdam: John Benjamins Publishing Company.

[27] Sportiche, Dominique, at all. 2014. An Introduction to Syntactic Analysis and Theory. Wiley \& SonsLtd. Publication.

[28] VanValin, Jr., R. D. 2004. An Introduction of Syntax. Cambridge: Cambridge University Press.

[29] VanValin, Jr., R. D. 2005. Exploring the Syntanx-Semantics Interface. Cambridge: Cambridge University Press.

[30] Zagona, K. 2003. The Syntax of Spanish. Cambridge: Cambridge University Press. 